\title{
Vertical Distribution of Phosphates in the Black Sea Based on the Expeditionary Data, 2016-2019
}

\author{
S. I. Kondratev ${ }^{凶}$, D. S. Khoruzhii \\ Marine Hydrophysical Institute of RAS, Sevastopol, Russian Federation \\ 凶skondratt@mail.ru
}

Purpose. The purpose of the study is to analyze the features of vertical distribution of phosphates and dissolved organic phosphorus (Porg) in the Black Sea at the present period.

Methods and Results. The data obtained by the scientists of Marine Hydrophysical Institute in the Black Sea within the economic zone of Russia in 2016-2019 were used. At more than 200 deepsea stations, a cassette of 12 bathometers (the Seabird-Electronics STD-instrument) was applied for taking hydrochemical samples at certain isopycnic surfaces, usually at $\sigma_{\mathrm{t}}=16.30 ; 16.25 ; 16.20$; $16.20 ; 16.15 ; 16.10 ; 16.05 ; 16.00 ; 15.95 ; 15.90 ; 15.80 ; 15.50,14.0 \mathrm{~kg} / \mathrm{m}^{3}$. At the coastal shallowwater stations, samples were taken at the $10 \mathrm{~m}$ intervals. Such a scheme permitted to carry out vertical sampling in the upper mixed layer and in the suboxic zone (including its upper boundary) with possible minimum of phosphates, to determine the depth of hydrogen sulfide formation and the location of the phosphates concentration maximum in the upper part of the anaerobic zone.

Conclusions. From the surface to isopycn $\sigma_{\mathrm{t}}=14.4 \mathrm{~kg} / \mathrm{m}^{3}$, the content of phosphates and Porg does not exceed $0.1 \mu \mathrm{M}$; below this isopycnic surface, the phosphates concentration begins to increase, whereas of Porg remains at the same level. At all the profiles of the phosphates vertical distribution, the phosphates concentration minimum was recorded near the isopycnic surface $\sigma_{\mathrm{t}}=15.8 \mathrm{~kg} / \mathrm{m}^{3}$, and its maximum - near the isopycnic surface $\sigma_{\mathrm{t}}=16.2 \mathrm{~kg} / \mathrm{m}^{3}$. The minimum content of phosphates varied within 0-1.5 $\mu \mathrm{M}$; in 2016-2017 the phosphates concentration maximum did not exceed $8 \mu \mathrm{M}$; in 2018, in many cases, it was higher than $12 \mu \mathrm{M}$, and once, near the Kerch Strait, it exceeded $17 \mu \mathrm{M}$. Increase in the magnitude of the maximum phosphates concentration (in the previous studies in 19882013, it did not exceed $8 \mu \mathrm{M}$ ) is assumed to be related to installation of the supports for constructing the Kerch Bridge.

Keywords: Black Sea, hydrogen sulfide formation, nutrients, vertical distribution of phosphates, field data

Acknowledgments: the investigation was carried out within the framework of the state task on theme No. 0555-2021-0004 "Fundamental studies of the oceanological processes which determine the state and evolution of the marine environment influenced by natural and anthropogenic factors, based on the observation and modeling methods".

For citation: Kondratev, S.I. and Khoruzhii, D.S., 2021. Vertical Distribution of Phosphates in the Black Sea Based on the Expeditionary Data, 2016-2019. Physical Oceanography, [e-journal] 28(5), pp. 538-548. doi:10.22449/1573-160X-2021-5-538-548

DOI: $10.22449 / 1573-160 X-2021-5-538-548$

(c) S. I. Kondratev, D. S. Khoruzhii, 2021

(C) Physical Oceanography, 2021

\section{Introduction}

Phosphorus is one of the key biogenic elements, whose content of inorganic compounds in the environment controls the primary production processes in the freshwater and marine ecosystems. The biotic circulation of phosphorus in the upper production water layer includes consumption of its low-molecular, mostly inorganic compounds, by phyto- and bacterio-plankton, regeneration of these compounds in the life processes of planktonic organisms, and also mineralization of organic phosphorus $\left(\mathrm{P}_{\text {org }}\right)$ to phosphates, which present in water 
in the form of the ortho-phosphoric acid anions, mainly in the form of a $\mathrm{HPO}_{4}{ }^{2-}$ anion. The only way to remove phosphorus from the marine environment is its burial in sediments [1]. In the oxygen-containing waters at the bottom, a significant amount of phosphorus is bound in the sediments with hydrated phosphates of iron(III) or calcium (fluorapatite $\left.\mathrm{Ca}_{5}\left(\mathrm{PO}_{4}\right)_{3} \mathrm{~F}\right)$. However, under the anoxia conditions, the burial of phosphorus bound by iron, is generally assumed to be relatively small due to the reductive dissolution of Fe(III) oxides-hydroxides and the release of bound phosphorus in the form of phosphates, although the latter can bind with $\mathrm{Fe}^{2+}$ forming vivianitis $\mathrm{Fe}(\mathrm{II})_{3}\left(\mathrm{PO}_{4}\right)_{2} \cdot 8 \mathrm{H}_{2} \mathrm{O}[1]$.

For the Black Sea and other water basins where there is a deficiency or complete absence of oxygen (for example, the Baltic Sea, the Cariaco Basin, the Norwegian fiords), dissolution of phosphates deposited on the $\mathrm{Fe}^{3+}$ oxides-hydroxides under the reducing conditions is especially important, since it occurs in the water column at the boundary where the hydrogen sulfide arises [2-5]. The cycles of phosphorus, sulfur and transition metals (iron and manganese) which are involved in the redox processes at the contact boundary between the oxygen and hydrogen sulfide zones, are closely related. In the bottom sediments, the redox transformations take place on a scale of a few centimeters; whereas in the deep part of the Black Sea, these processes are stretched vertically in the water column by meters.

The most important feature of the phosphates vertical profile in the Black Sea is the intermediate maximum of their content on the isopycnic surface $16.2 \mathrm{~kg} / \mathrm{m}^{3}$ [6-8]. It is assumed that although this maximum cannot serve a reference point for global assessing the phosphorus fluxes in the Black Sea [9], its value will change as a result of the processes taking place in the photic zone of the sea. The development of the Black Sea eutrophication in the early 70ies seems has led to the fact that the phosphates maximum located at the isopycn $16.4 \mathrm{~kg} / \mathrm{m}^{3}$ in 1969 amounted $<6 \mu \mathrm{M}$ in 1969, whereas in 1990 it was recorded at the isopycn $16.2 \mathrm{~kg} / \mathrm{m}^{3}$ and its value increased to $\sim 7.5 \mu \mathrm{M}$ [7]. In the studies performed in 1995-2015 [9-14], this value of the phosphates maximum remained practically unchanged.

The detailed studies of the phosphate content in the Black Sea were last performed by the scientists of Marine Hydrophysical Institute (MHI) during the expedition of R/V Professor Kolesnikov in 1995 [9], further such determinations were of a sporadic character. In particular, in 2004, the phosphates distribution was studied in the anticyclonic eddy over the continental slope in the region of the northwestern shelf [11], and the phosphates content in the region of the acting mud volcanoes was determined in the $61^{\text {st }}$ cruise of $\mathrm{R} / \mathrm{V}$ Professor Vodyanitsky [15]. In 2015-2018, MHI resumed expeditionary research in the Black Sea within the economic zone of Russia and conducted 10 expeditions which included determination of the phosphates and dissolved organic phosphorus content. The vertical profiles of the phosphorus compounds in the deep part of the sea obtained in these cruises have not been discussed yet. Examination of the features of these profiles and, particularly, the reasons for increase of the phosphates maximum concentration in the area adjacent to the Kerch Strait, is the purpose of the study. 


\section{Materials and methods}

The layout of hydrochemical stations in 10 cruises (2016-2018), at which the samples for determining the phosphates and $\mathrm{P}_{\text {org }}$ contents were taken, is shown in Fig. 1. The deep-sea hydrochemical samples were taken using a cassette of 12 bathometers (the Seabird-Electronics STD-instrument) at certain isopycnic surfaces; as a rule, it was a series of isopycnes $16.30 ; 16.25$; $16.20 ; 16.15 ; 16.10$; $16.05 ; 16.00 ; 15.95 ; 15.90 ; 15.80 ; 15.50 ; 14.0 \mathrm{~kg} / \mathrm{m}^{3}$. Such a vertical sampling scheme made it possible to determine the depth at which hydrogen sulfide arises, the thickness of the layers with different oxygen content, and the location of the phosphates minimum and maximum concentrations with an accuracy to $\sigma_{t}=0.05 \mathrm{~kg} / \mathrm{m}^{3}$ (or up to $5 \mathrm{~m}$ on the depth scale). No samples for determining phosphates below the isopycn $16.30 \mathrm{~kg} / \mathrm{m}^{3}$ were taken in 2016-2018, since the accuracy of the method were affected by hydrogen sulfide.

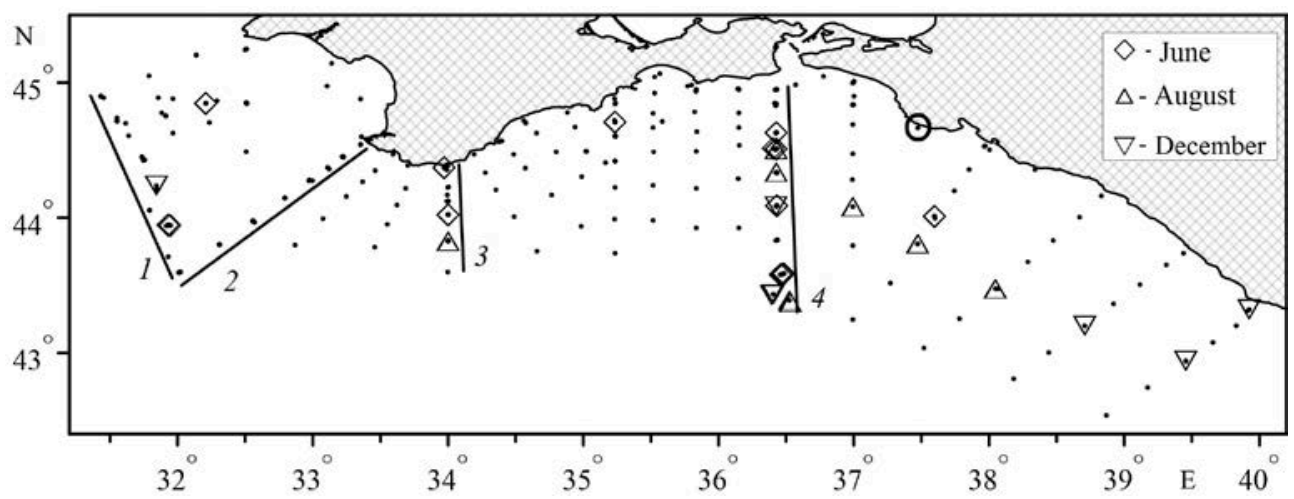

F i g. 1. Map of the sampling stations for determining the phosphates content in 2016-2018. Large symbols denote the stations, where, in 2018, the maximum phosphates concentration exceeded $10 \mu \mathrm{M}$. Solid lines indicate sections 1-4 in June, 2018

The content of phosphates and total dissolved phosphorus was determined by the method described in [16]. The sample was filtered through the $450 \mathrm{~nm}$ filter, the filtrate was oxidized by heating with potassium persulfate, thus organic phosphorus was converted into phosphates. In 2016-2019, the water samples were stored and transported in accordance with the method requirements, and GOST 31861-2012 and GOST 17.1.5.05-85. According to the method, the minimum detectable phosphates concentration was $0.053 \mu \mathrm{M}\left(5.00 \mathrm{mg} / \mathrm{m}^{3}\right)$ (RD 52.10.738-2010).

\section{The obtained results and their discussion The phosphate content in the upper productive layer of the Black Sea waters in 2016-2018.}

The features of vertical distribution of the phosphorus compounds in the deeper layers of the water column will be considered on the conditional density scale, as it has been accepted in the Black Sea studies since the end of the last century [6, 8]. First of all, vertical distributions of the phosphates and $\mathrm{P}_{\text {org }}-$ component concentrations in the surface waters should be compared. There is no 
much information on the $\mathrm{P}_{\text {org }}$ content in the Black Sea, since its determination is much more laborious. The distributions of the phosphates and $\mathrm{P}_{\text {org }}$ content shown in Fig. 2 do not permit to deduce any regularity. The concentrations of both components from the surface up to the range $14.4-14.5 \mathrm{~kg} / \mathrm{m}^{3}$ (deeper, oxycline arises) are low, the organic phosphorus content is about the same as of the phosphate. The low concentrations of phosphates and $\mathrm{P}_{\text {org }}$ made it impossible to trace any seasonal changes in the content of these components in the photic zone.

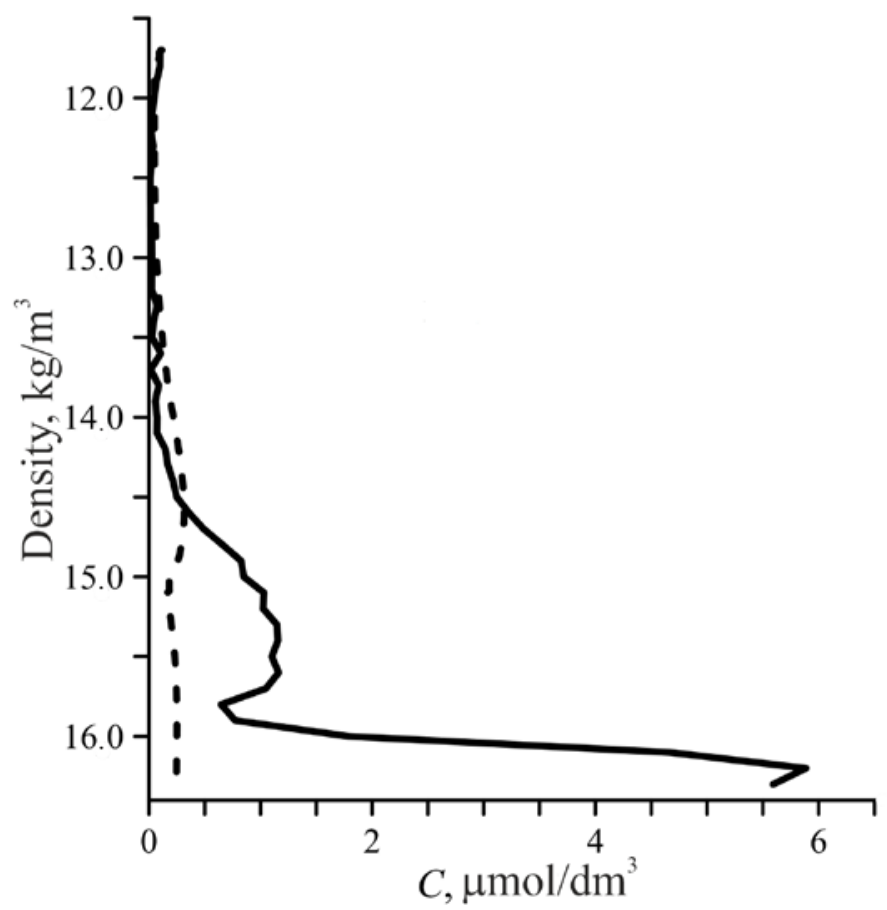

F i g. 2. Averaged vertical profiles of phosphates (solid line) and $P_{\text {org }}$ (dashed line) in the density coordinates based on all the expeditionary data obtained in 2016-2017

Below $\sigma_{t}=14.4-14.5 \mathrm{~kg} / \mathrm{m}^{3}$, the phosphate content increases reaching the concentrations $>1 \mu \mathrm{M}$ at the isopycn $15.5 \mathrm{~kg} / \mathrm{m}^{3}$; further it decreases and amounts $<0.5 \mu \mathrm{M}$ at $\sigma_{t}=15.8 \mathrm{~kg} / \mathrm{m}^{3}$, then monotonically increases to $6.5 \mu \mathrm{M}$ at the upper boundary of the hydrogen sulfide zone. The $\mathrm{P}_{\text {org }}$ content in water remains approximately the same within the whole range of densities.

\section{Changes in the vertical profiles at the hydrogen sulfide bedding boundary in 2016-2019.}

It was noted above that a distinctive feature of the phosphates vertical distribution in the Black Sea was their maximum at the boundary of the hydrogen sulfide arise. Since the phosphates concentration in the upper productive water layer is low and varies insignificantly with depth, the vertical profiles and distributions on the sections given below start from $14.0 \mathrm{~kg} / \mathrm{m}^{3}$ and come to end at the isopycn $16.3 \mathrm{~kg} / \mathrm{m}^{3}$. Fig. 3 shows the vertical profiles of phosphate distribution PHYSICAL OCEANOGRAPHY VOL. 28 ISS. 5 (2021) 
obtained by the foreign researchers in 1969-2008 and by the MHI scientists in different years.
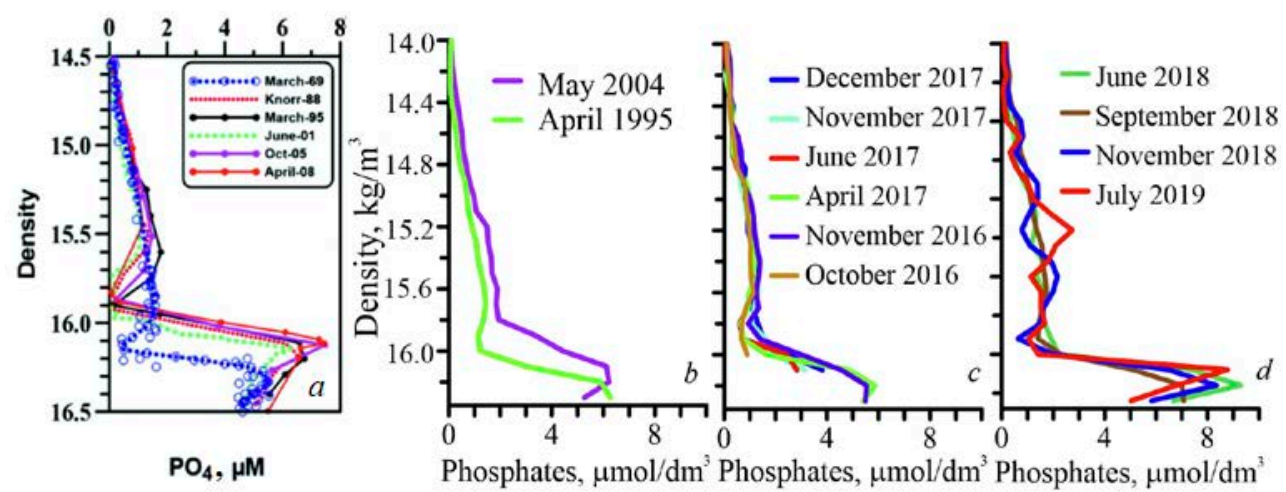

F i g. 3. Averaged vertical profiles of phosphates $(\mu \mathrm{M})$ based on [13, p. 40] (a) and the results of MHI studies in 1995 and $2004(b)$, and in 2016-2019 (c, d)

It is seen in Fig. 3, $a$ that in 1969 the phosphates maximum concentration in the Black Sea was $<6 \mu \mathrm{M}$, in 1988 it slightly increased, but did not reach $7 \mu \mathrm{M}$ $[6,8]$; in 1995-2006 it was within 7.0-7.5 $\mu \mathrm{M}$ [9-11]; in 2013, in the center of the western cyclonic gyre, its value was $7.5 \mu \mathrm{M}[13,14]$. In other words, in course of 25 years (1988-2013), the phosphates maximum concentration at the boundary of the hydrogen sulfide zone remained practically constant and did not reach $8 \mu \mathrm{M}$.

Taking into account such a constant maximum value during 25 years, we expected that it would not change in the subsequent years. Indeed, in 2016-2017 it did not exceed $8 \mu \mathrm{M}$ (Fig. 3, c), but in 2018 it unexpectedly increased and in some cases reached $12 \mu \mathrm{M}$. These values are not manifested in the averaged profiles in Fig. 3, but they evidently influenced the phosphates vertical distribution at the sections (see below). The concentrations exceeding $8 \mu \mathrm{M}$ were obtained in all three surveys in 2018, i.e., they are not a single outlier from the data set, which resulted from an analytical error. The phosphate concentration $12.1 \mu \mathrm{M}$ was recorded at the depth $200 \mathrm{~m}$ on the northeastern shelf [17] (where sampling was carried at the standard horizons, not at isopycnes).

\section{The phosphates vertical distribution at the sections.}

Most of the stations at which the increased phosphate concentrations were recorded in 2018 are located to the south of the Kerch Strait (section 4), and, in several cases, to the east and west of section 4 (Fig. 1). The phosphates vertical distribution at section 4 in December, 2017 (Fig. 4, a) was similar to that observed in 1988-2013. At 5 stations of 6 , the minimum $(<1 \mu \mathrm{M})$ was recorded on the isopycn of $15.8 \mathrm{~kg} / \mathrm{m}^{3}$; then, up to the isopycn $16.2 \mathrm{~kg} / \mathrm{m}^{3}$, the concentrations gradually grew, but however, did not exceed $7 \mu \mathrm{M}$. 


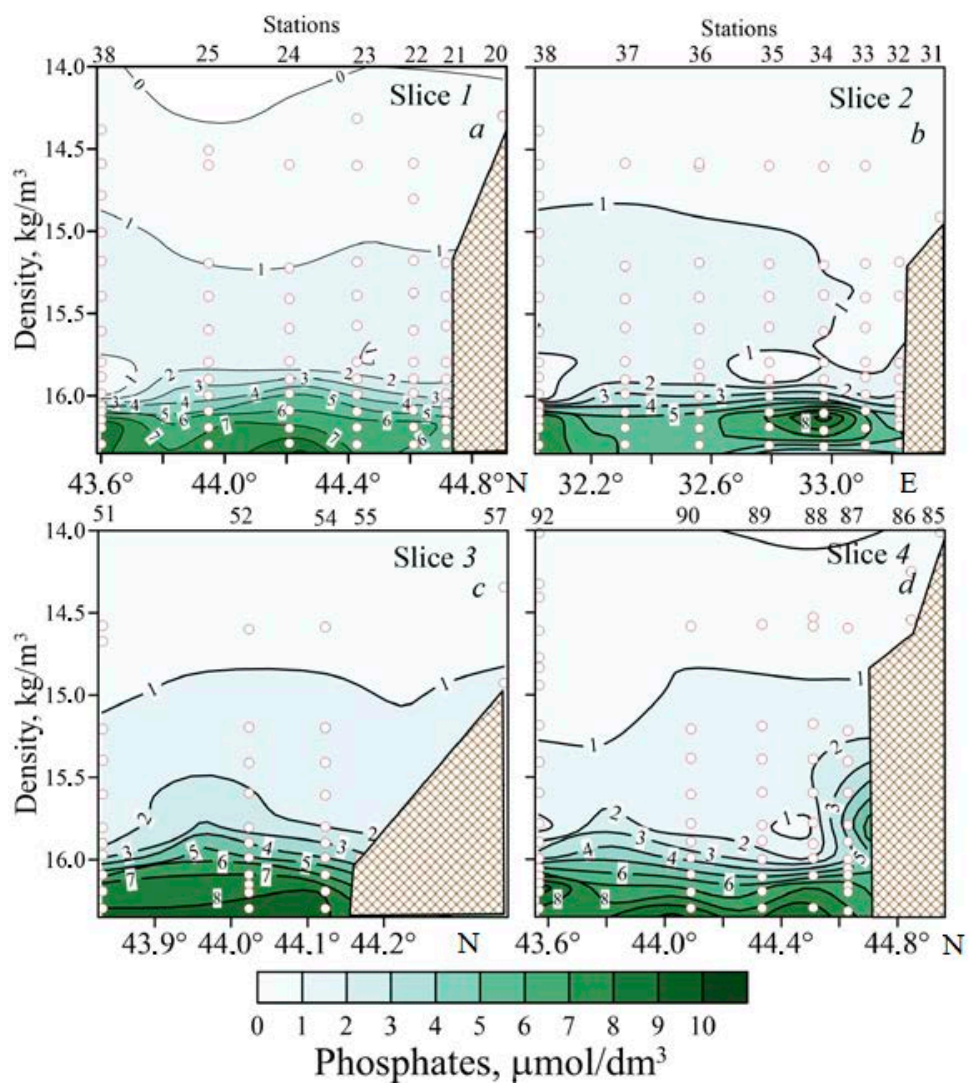

F i g. 4. Distribution of phosphates at section 4 to the south of the Kerch Strait in December, 2017 December, 2018

In June, 2018 (Fig. 4, b), almost the whole section did not show a minimum of the phosphate concentration on the $15.8 \mathrm{~kg} / \mathrm{m}^{3}$ isopycn; the concentration smaller than $1 \mu \mathrm{M}$ on this isopycn was observed only at the southernmost station of the section. At two northern stations, the concentration $2 \mu \mathrm{M}$ was observed at the $15.5 \mathrm{~kg} / \mathrm{m}^{3}$ isopycn (in December, it was recorded at the $16.0 \mathrm{~kg} / \mathrm{m}^{3}$ isopycn); and between the isopycnes 15.5 and $16.0 \mathrm{~kg} / \mathrm{m}^{3}$, it increased to $3-4 \mu \mathrm{M}$. At two stations, the phosphate maximum exceeded $8 \mu \mathrm{M}$, and at the southernmost station it was $10 \mu \mathrm{M}$. Based on these data, one can assume that the current directed from the Azov Sea to the Black Sea brought the increased phosphates concentrations to the bottom water layers in the Kerch Strait region.

By August, the phosphates content in the bottom water layers slightly decreased, and the concentration minima $<1 \mu \mathrm{M}$ were observed on the isopycn $15.8 \mathrm{~kg} / \mathrm{m}^{3}$ in the southern part of the section; but the concentration maxima $>8 \mu \mathrm{M}$ remained in the region $44.5^{\circ} \mathrm{N}$, as well as at the southern end of the section (Fig. 4, c). In December, within the range of conditional densities $15.5-16.0 \mathrm{~kg} / \mathrm{m}^{3}$, the phosphates content increased again to $2 \mu \mathrm{M}$ and higher, the minima at the $15.8 \mathrm{~kg} / \mathrm{m}^{3}$ isopycn disappeared, however the maximum values in the northern part of the section decreased to $6 \mu \mathrm{M}$, at that at the southernmost station, the concentration exceeded $7 \mu \mathrm{M}$ (Fig. 4, d). 
Summarizing the foregoing features, one can briefly conclude that increase in the phosphates concentrations at section 4 in June, 2018, as compared to those in December, 2017, is explained by the phosphates additional inflow from the Kerch Strait. In half a year in December, 2018, their inflow became less intense, although the phosphates maximum concentration in the southern part of the section has not yet decreased to the standard value $8 \mu \mathrm{M}$.

It seen that the strongest changes in the phosphates vertical distribution in the Kerch Strait region were observed in June, 2018. At this time in the other regions of the polygon under study, similar changes were also noted, less noticeable the farther from the Kerch Strait the region was located (Fig. 5). At section 4 , the phosphates concentrations $>9 \mu \mathrm{M}$ on the isopycn $16.2 \mathrm{~kg} / \mathrm{m}^{3}$ were observed at all the stations; to the west at section 3 , their content exceeding $8 \mu \mathrm{M}$ on the same isopycn was recorded only at three stations; even further west, at sections 2 (the Cape Chersonesos - the Bosphorus Strait) and 1 (the northwestern shelf), the maximum content $>8 \mu \mathrm{M}$ was recorded only at one station.
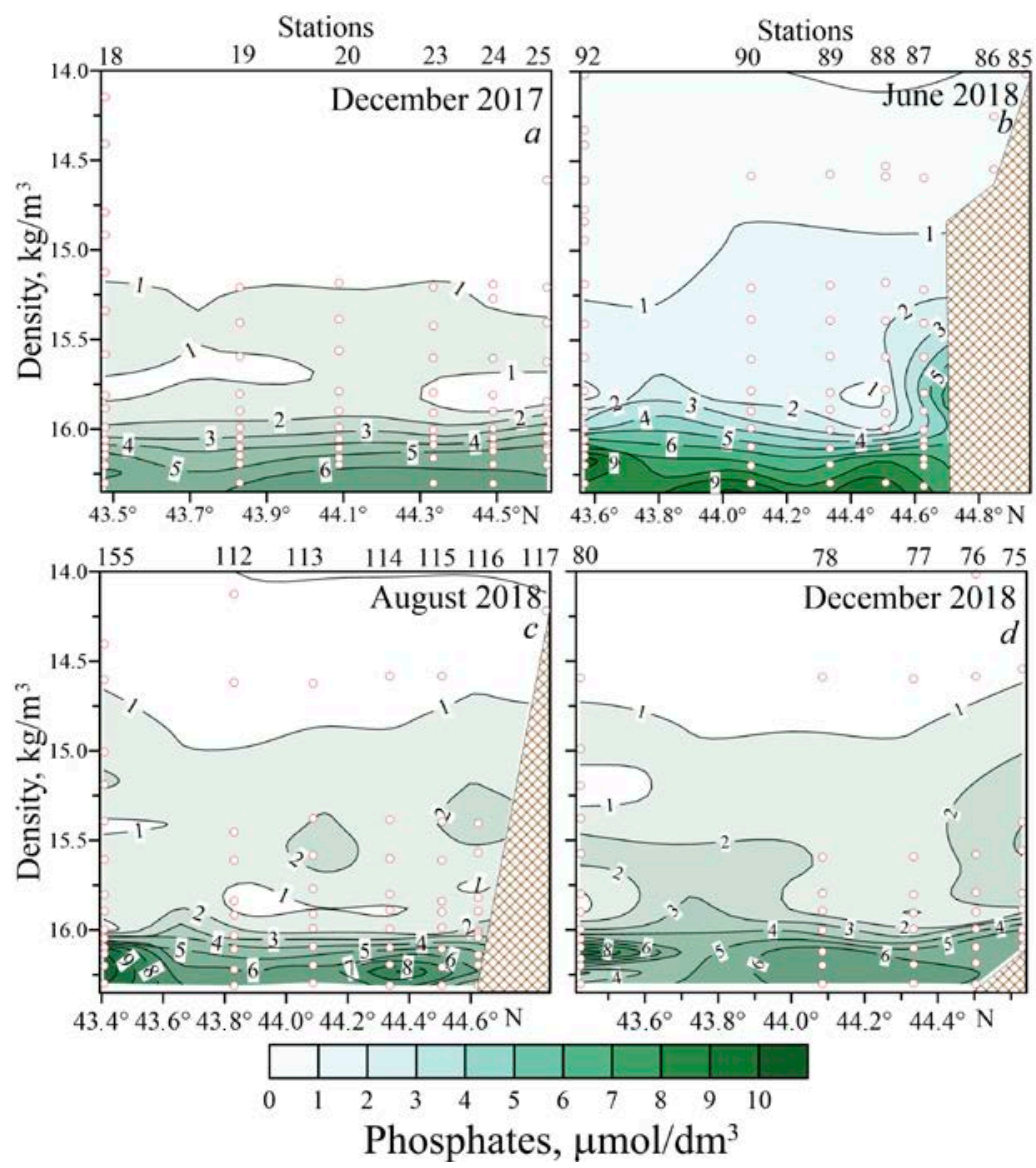

F i g. 5. Vertical distribution of phosphates at sections 1-4 in June, 2018 


\section{"Shuttle" transfer of phosphates near the boundary of the hydrogen sulfide zone.}

In 1986, G. Schaeffer was the first to describe the phosphates vertical profile in the Black Sea with the minimum and maximum concentrations, having called it "the large phosphate anomaly dipole" [18, p. 515]. He assumed the existence of a "shuttle" for transporting the phosphates in the form of rapidly descending metal oxides. The $\mathrm{Fe}^{3+}$ oxides existing in the oxygen-containing zone adsorb phosphates and form a solid phase, in which, when it submerges into the oxygen-free zone, the $\mathrm{Fe}^{3+}$ ions are reduced to the $\mathrm{Fe}^{2+}$ ions which exist in the dissolved form. Due to diffusion, the latter ( $\mathrm{Fe}^{2+}$ ions) rise to the oxygen-containing zone where they are oxidized to $\mathrm{Fe}^{3+}$, transform into the suspended form, again adsorb phosphates, submerge and so on. The minimum on the vertical profile corresponds to the state when all the phosphates are adsorbed on the $\mathrm{Fe}^{3+}$ oxides, the maximum - when all the $\mathrm{Fe}^{3+}$ oxides have been reduced to a soluble form of $\mathrm{Fe}^{2+}$ and "have given back" the phosphates to the water column.

The quantitative estimates allowed G. Schaeffer to explain about $40 \%$ of the phosphates transport at the interface between the oxygen-containing and hydrogen sulfide waters. Further study of the phosphate transfer mechanism showed that the manganese compounds were also involved in this process [19-22]. The detailed study of the "iron shuttle" structure based on the data from [14], showed that it was an intricate complex, in which a cluster of phosphates on the iron (III) oxide-hydroxide moved up and down as a part of magneto-bacteria. By whichever of the mechanisms the phosphates cross the hydrogen sulfide boundary, the most important feature is the dissolution of phosphates sorbed by the $\mathrm{Fe}^{3+}$ oxides-hydroxides during their reducing in the hydrogen sulfide layer.

The reason of increase in the phosphates maximum concentration on the isopycn $16.2 \mathrm{~kg} / \mathrm{m}^{3}$ in 2018 revealed in the MHI expeditions is, in our opinion, associated with the construction of the Kerch Bridge. From the side of the Crimea coast, the bridge supports are located 2-3 km to the north of the Kamysh-Burunsky iron ore deposit, and from the mainland side $-3 \mathrm{~km}$ to the north of the Cape Zhelezny Rog. It means that the bridge is located over the iron ore deposits which includes not only the hydrated iron oxides (goethite, limonite, etc.), but also azovskite $\mathrm{Fe}_{3}\left(\mathrm{PO}_{4}\right)_{2}(\mathrm{OH})_{3}$ containing phosphate. Construction of the pile foundations of the Kerch Bridge supports on land began on March, 10 and in the sea areas - on May 17, 2016. By the beginning of 2018, almost all the piles for the automobile and railway parts of the future bridge, more than 6.5 thousand, were installed. Some of them were driven into the ground to a depth $105 \mathrm{~m}$ that corresponds to the height of a 35-storey building (https://tass.ru/info/5200479).

One should assume that when drilling the bottom to install the bridge supports, significant amount of the bottom sediments in the form of suspended matter were raised to the seawater. This process had no any effect on the phosphates concentration in the surface waters, since the iron phosphates contained in the sediments were in a bound form. The suspension was gradually transported to the Black Sea by the current; there (presumably at the beginning of 2018) it reached the shelf edge and while settling, it gradually reached the hydrogen sulfide zone with its reducing conditions. The subsequent reduction of phosphate $\mathrm{Fe}^{3+}$ to 
phosphate $\mathrm{Fe}^{2+}$ resulted, according to the scheme described above, in transition of the phosphates to the aqueous phase.

Due to the eastern cyclonic circulation, the layer with the increased phosphates content at the hydrogen sulfide zone boundary spread mainly to the southeastern part of the sea [23] (east of section 4). This layer was transferred by the Rim Current also to the west reaching $34^{\circ} \mathrm{E}$ (section 3 ) and, in some cases, even sections 2 and 1 (Fig. 1). The increased phosphate concentrations may have occurred in the northeastern part of the sea prior to 2018 (in particular, [17] reports on the phosphate concentration $375 \mathrm{mg} / \mathrm{m}^{3}(\approx 12 \mu \mathrm{M})$ at the $200 \mathrm{~m}$ depth), but in 20162017 MHI did not perform hydrochemical studies to the east of the Kerch Strait.

The assumption of the authors about the influence of a large-scale construction on the vertical transport of phosphorus compounds over a large part of the adjacent water area permits to explain high phosphates concentration $(>10 \mu \mathrm{M})$ at the coastal station $\left(44^{\circ} 40^{\prime} \mathrm{N}, 37^{\circ} 35^{\prime} \mathrm{E}\right.$; marked by a circle in Fig. 1) at the $55 \mathrm{~m}$ depth $\left(\mathrm{t} \sigma_{\mathrm{t}}=14.4 \mathrm{~kg} / \mathrm{m}^{3}\right)$ and its maximum value $(17 \mu \mathrm{M})$ at $44^{\circ} 30^{\prime} \mathrm{S}$ (section 4$)$ in June, 2018.

\section{Conclusions}

Analysis of the data on the phosphates and dissolved organic phosphorus vertical distributions from the surface to the isopycn $16.3 \mathrm{~kg} / \mathrm{m}^{3}$ obtained in 10 expeditions of Marine Hydrophysical Institute in the Black Sea (economic zone of Russia) in 2016-2018 permits to conclude that:

1. The phosphates and $P_{\text {org }}$ content from the surface to the isopycn $14.4 \mathrm{~kg} / \mathrm{m}^{3}$ did not exceed $0.1 \mu \mathrm{M}$; below, the phosphates concentration increased, whereas the $\mathrm{P}_{\text {org }}$ concentration remained approximately the same.

2. On all the profiles, the phosphates minimum concentrations $(0-1.5 \mu \mathrm{M})$ were recorded at $\sigma_{t}=15.8 \mathrm{~kg} / \mathrm{m}^{3}$ and the maximum ones - at $\sigma_{t}=16.2 \mathrm{~kg} / \mathrm{m}^{3}$. In 2016-2017, the maximum concentration was $\sim 8 \mu \mathrm{M}$; in 2018 in many cases, it exceeded $12 \mu \mathrm{M}$, and to the south of the Kerch Strait it reached $17 \mu \mathrm{M}$. Such an increase in the values at the upper boundary of the hydrogen sulfide zone is assumed to be related to additional amount of the inorganic phosphorus compounds formed as a result of the Kerch Bridge construction.

\section{REFERENCES}

1. Dijkstra, N., Kraal, P., Kuypers, M.M.M., Schnetger, B. and Slomp, C.P., 2014. Are IronPhosphate Minerals a Sink for Phosphorus in Anoxic Black Sea Sediments? PLoS ONE, 9(7), e101139. https://doi.org/10.1371/journal.pone.0101139

2. Kraal, P., Yücel, M. and Slomp, C.P., 2019. Turbidite Deposition and Diagenesis in the Southwestern Black Sea: Implications for Biogeochemical Cycling in an Anoxic Basin. Marine Chemistry, 209, pp. 48-61. doi:10.1016/j.marchem.2019.01.001

3. Gordey, A.S. and Chechueva, N.S., 2019. Hydrochemical Conditions in the South-Eastern Part of the Baltic Sea in 2018. Proceedings of Moscow Institute of Physics and Technology, 11(4), pp. 68-81 (in Russian).

4. Scranton, M.I., Taylor, G.T., Thunell, R., Benitez-Nelson, C.R., Muller-Karger, F., Fanning, K., Lorenzoni, L., Montes, E., Varela, R. and Astor, Y., 2014. Interannual and Subdecadal Variability in the Nutrient Geochemistry of the Cariaco Basin. Oceanography, 27(1), pp. 148159. http://dx.doi.org/10.5670/oceanog.2014.18 
5. Pakhomova, S., Braaten, H.F.V., Yakushev, E. and Skei, J., 2014. Biogeochemical Consequences of an Oxygenated Intrusion into an Anoxic Fjord. Geochemical Transactions, 15, 5. doi:10.1186/1467-4866-15-5

6. Murray, J.W., Ed., 1991. Black Sea Oceanography: Results from the 1988 Black Sea Expedition. Deep Sea Research Part A. Oceanographic Research Papers, 38(Suppl. 2), pp. S655-S1266.

7. Konovalov, S.K. and Murray, J.W., 2001. Variations in the Chemistry of the Black Sea on a Time Scale of Decades (1960-1995). Journal of Marine Systems, 31(1-3), pp. 217-243. doi:10.1016/S0924-7963(01)00054-9

8. Murray, J.W., 2005. Special Issue on Black Sea Oceanography. Oceanography, 18(2), pp. 1415. https://doi.org/10.5670/oceanog.2005.37

9. Konovalov, S.K. and Eremeev, V.N., 2012. [Regional Features, Stability, and Evolution of Biochemical Structure of the Black Sea Waters]. In: V. N. Eremeev, S. K. Konovalov, Eds., 2012. [Stability and Evolution of Oceanological Characteristics of the Black Sea Ecosystems]. Sevastopol: ECOSI-Gidrofizika, pp. 273-299 (in Russian).

10. Eremeeva, L.V., Romanov, A.S., Ovsjanyj, E.I., Dolotov, V.V. and Konovalov, S.K., 1995. [Hydro-Chemical Studies in the 33rd Cruise of $R / V$ "Professor Kolesnikov"]. Preprint. Sevastopol: MHI, 43 p. (in Russian).

11. Krastev, A., Shtereva, G., Hristova, O. and Dzhurova, B., 2006. Nutrients in the Western Black Sea Area. Spatial and Vertical Distribution. In: Commission on the Protection of the Black Sea against Pollution, 2006. Proceedings of the First Biannual Scientific Conference: Black Sea Ecosystem 2005 and Beyond. Istanbul, Turkey, pp. 93-105.

12. Kontrat'ev, S.I., Romanov, A.S. and Vnukov, Yu.L., 2007. Peculiarities of Distribution of Hydrochemical Characteristics in the Region of the Continental Slope of the Northwestern Black Sea. Morskoy Gidrofizicheskiy Zhurnal, (5), pp. 69-79 (in Russian).

13. Tuğrul, S., Murray, J.W., Friederich, G.E. and Salihoğlu, İ., 2014. Spatial and Temporal Variability in the Chemical properties of the Oxic and Suboxic Layers of the Black Sea. Journal of Marine Systems, 135, pp. 29-43. https://doi.org/10.1016/j.jmarsys.2013.09.008

14. Schulz-Vogt, H.N., Pollehne, F., Jürgens, K., Arz, H.W., Beier, S., Bahlo, R., Dellwig, O., Henkel, J.V., Herlemann, D.P.R., Krüger, S., Leipe, T. and Schott, T., 2019. Effect of Large Magnetotactic Bacteria with Polyphosphate Inclusions on the Phosphate Profile of the Suboxic Zone in the Black Sea. The ISME Journal, 13, pp. 1198-1208. https://doi.org/10.1038/s41396-018-0315-6

15. Shnyukov, E.F., Goryachkin, J.N. and Kondratyev, S.I., 2006. Hydrogen Sulphide, Phosphates and Silicic Acid in the Bottom Waters of the Black Sea near Mud Volcanoes. Geology and Mineral Resources of World Ocean, (1), pp. 55-64.

16. Grasshoff, K., Ehrhardt, M. and Kremling, K., Eds., 1983. Methods of Seawater Analysis. Weinheim: Verlag Chemie, 419 p.

17. Baskakova, T.E., Kosenko, Yu.V. and Burdina, E.I., 2019. Spatio-Temporal Features of the Nutrients Dynamics in the Northeastern Black Sea. Aquatic Bioresources \& Environment, 2(1), pp. 7-19. doi:10.47921/2619-1024_2019_2_1_7 (in Russian).

18. Shaffer, G., 1986. Phosphate Pumps and Shuttles in the Black Sea. Nature, 321(6069), pp. 515-517. https://doi.org/10.1038/321515a0

19. Delwig, O., Leipe, T., März, C., Glockzin, M., Pollehne, F., Schnetger, B., Yakushev, E.V., Bötcher, M.E. and Brumsack, H.-J., 2010. A New Particulate Mn-Fe-P-Shuttle at the Redoxcline of Anoxic Basins. Geochimica et Cosmochimica Acta, 74(24), pp. 7100-7115. https://doi.org/10.1016/j.gca.2010.09.017 
20. Jilbert, T. and Slomp, C.P., 2013. Iron and Manganese Shuttles Control the Formation of Authigenic Phosphorus Minerals in the Euxinic Basins of the Baltic Sea. Geochimica et Cosmochimica Acta, 107, pp. 155-169. https://doi.org/10.1016/j.gca.2013.01.005

21. Hermans, M., Lenstra, W.K., van Helmond, N.A.G.M., Behrends, T., Egger, M., Seguret, M.J.M., Gustafsson, E., Gustafsson, B.G. and Slomp, C.P., 2019. Impact of Natural Re-Oxygenation on the Sediment Dynamics of Manganese, Iron and Phosphorus in a Euxinic Baltic Sea Basin. Geochimica et Cosmochimica Acta, 246, pp. 174-196. https://doi.org/10.1016/j.gca.2018.11.033

22. Lenstra, W.K., Séguret, M.J.M., Behrends, T., Groeneveld, R.K., Hermans, M., Witbaard, R. and Slomp, C.P., 2020. Controls on the Shuttling of Manganese over the Northwestern Black Sea shelf and Its Fate in the Euxinic Deep Basin. Geochimica et Cosmochimica Acta, 273, pp. 177-204. https://doi.org/10.1016/j.gca.2020.01.031

23. Ivanov, V.A. and Belokopytov, V.N., 2013. Oceanography of the Black Sea. Sevastopol: ECOSI-Gidrofizika, $210 \quad$ p. Available at: https://www.researchgate.net/publication/236853664_Ivanov_VA_Belokopytov_VN_Oceano graphy_of_the_Black_Sea_National_Academy_of_Sciences_of_Ukraine_Marine_Hydrophys ical_Institute_Sevastopol_210_p [Accessed: 06 September 2021].

About the authors:

Sergey I. Kondratyev, Senior Researcher, Marine Hydrophysical Institute of RAS (2 Kapitanskaya St., Sevastopol, 299011, Russian Federation), Candidate of Chemical Sciences, ORCID ID: 0000-0002-2049-7750, skondratt@mail.ru

Dmitrii S. Khoruzhii, Junior Researcher, Marine Hydrophysical Institute of RAS (2 Kapitanskaya St., Sevastopol, 299011, Russian Federation), ORCID ID: 0000-0003-1411-1441, Scopus Author ID: 36623812000, khoruzhiy@mhi-ras.ru

Contribution of co-authors:

Sergey I. Kondratyev - setting out the objectives and tasks of the research; analysis of literature data, analysis of materials on the research theme; participation in the discussion of the article materials; discussion of the study results; analysis and generalization of the research results, editing and supplementing the text of the article, formulation of the conclusions

Dmitrii S. Khoruzhii - handling of water samples and phosphates concentration measurement, analysis and preparation of initial conclusions, qualitative analysis of the results and their interpretation, construction of maps, graphs, figures, for the article; participation in the discussion of the article materials

All the authors have read and approved the final manuscript.

The authors declare that they have no conflict of interest. 